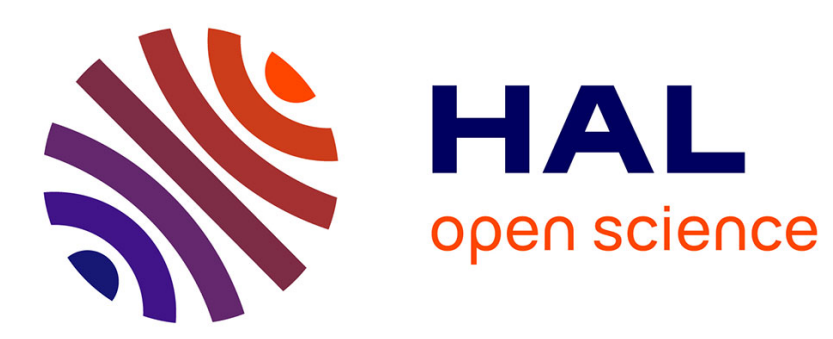

\title{
Crop protection, biological control, habitat management and integrated farming. A review
}

Pierre Ferron, Jean-Philippe Deguine

\section{To cite this version:}

Pierre Ferron, Jean-Philippe Deguine. Crop protection, biological control, habitat management and integrated farming. A review. Agronomy for Sustainable Development, 2005, 25 (1), pp.17-24. hal00886278

\section{HAL Id: hal-00886278 \\ https://hal.science/hal-00886278}

Submitted on 1 Jan 2005

HAL is a multi-disciplinary open access archive for the deposit and dissemination of scientific research documents, whether they are published or not. The documents may come from teaching and research institutions in France or abroad, or from public or private research centers.
L'archive ouverte pluridisciplinaire HAL, est destinée au dépôt et à la diffusion de documents scientifiques de niveau recherche, publiés ou non, émanant des établissements d'enseignement et de recherche français ou étrangers, des laboratoires publics ou privés. 


\title{
Crop protection, biological control, habitat management and integrated farming. A review
}

\author{
Pierre FERRONa ${ }^{\mathrm{a}}$, Jean-Philippe DEGUINE** \\ a INRA, 2 place Viala, 34060 Montpellier, France \\ ${ }^{\mathrm{b}}$ CIRAD, avenue Agropolis, 34398 Montpellier Cedex 5, France
}

(Received 6 November 2004; accepted 6 November 2004)

\begin{abstract}
In a context of rationalised agriculture integrating the principles of sustainable development, preventive measures for crop protection are called upon to play a dominant role. These preventive measures are based on close knowledge of the functioning of agroecosystems. They are aimed at managing biological pests and their natural enemies, first through action on their habitats both in crop fields and in the non-cultivated part of the farm. A balance of the biological control possibilities available is drawn up and attention paid to the application of recent knowledge in conservation biology. The bases of pest control with a ranking of the various intervention techniques are then set out. Implementation means the development of cropping systems and therefore increased participation by agronomists and also a break with certain agronomic practices commonly used by farmers today.
\end{abstract}

biodiversity / biological control / habitat management / integrated control / integrated farming

\section{INTRODUCTION}

Agriculture has been subjected to fresh socioeconomic pressure for about a decade, in particular following the globalisation of trade and the taking into account of the sustainable development concept. Thus Europe's common agricultural policy (CAP) now favours produce quality and simultaneously recommends the adoption of agri-environmental measures. To remain competitive in this new context, farmers must limit production costs and in particular reduce the quantities of inputs that hitherto enabled a continuous increase in yields. Crop management sequences and farming systems themselves can thus be called into question.

The protection of crops from organisms that are occasionally harmful (microbes and phytopathogenic viruses, animal pests and weeds) or biological pests is particularly affected by this development because of the scale of the costs involved and the unfavourable secondary effects on food chains and biological balances. Rich with various experience gained during the last century - significantly marked by the development and success of synthetic pesticides - crop protection may also experience a conceptual development, allowing it to progress from the stage of control of biological pests to that of population management applied to both pests and auxiliaries within the frame- work of increased mastery of the perennial functioning of agroecosystems.

\section{CROP PROTECTION: CONTROL OR MANAGEMENT?}

The traditional method for controlling biological pests is curative, consisting essentially of chemical methods thanks to the discovery, synthesis and marketing of pesticides with practically instant efficacy and ease of application but a finally substantial cost and, above all, frequently insufficient target specificity. Application is at best determined after prior diagnosis of the real risk at field level according to economic thresholds set for each crop for a given socioeconomic situation. Its success among farmers led to forgetting the interest initially shown in other methods - usually agronomic and preventive (fallows, cropping sequences, crop rotation, etc.). Today, alternative phytosanitary solutions are nevertheless recommended within the context of so-called integrated control but they have not really changed habits that are now firmly anchored, except in a few special cases in which phenomena of resistance to synthetic pesticides had led to notorious economic and crop health impasses [20].

\footnotetext{
* Corresponding author: jean-philippe.deguine@cirad.fr
} 
Figure 1. Integrated control, pest management and integrated pest management (IPM).

Integrated control is a pest management system that in the context of the associated environment and the population dynamics of the pest species uses all suitable techniques and methods in as compatible a manner as possible and maintains the pest populations at levels below those causing economic injury. It is not a simple juxtaposition or superposition of two control techniques (such as chemical and biological control) but the integration of all the management techniques suited to the natural regulation and limiting factors of the environment [19].

Pest management is the reduction of pest problems by actions selected after the life systems of the pests are understood and the ecological as well as economic consequences of these actions have been predicted, as accurately as possible, to be in the best interest of mankind. In the development of a pest management programme, priority is given to understanding the role of intrinsic and extrinsic factors in causing seasonal and annual change in pest populations [54].

Integrated pest management (IPM) is a pest containment strategy that seeks to maximise natural control forces such as predators and parasites and to use other tactics only as needed and with a minimum of environmental disturbance [24].

Figure 2. Integrated farming.

Integrated farming (or integrated crop management, ICM) is 'a holistic pattern of land use, which integrates natural regulation processes into farming activities to achieve a maximum replacement of off-farm inputs and to sustain farm income' [18].

Innovative measures were nevertheless recommended from 1967 onwards by FAO (Fig. 1) with the "integrated control" concept adopted a few years later by Californian scientists who used the expression "integrated pest management" or IPM. The latter phrase meant that attention was drawn significantly to the conceptual difference between the notions of control and management. Unfortunately, application of the new approach, illustrated in particular in the USA by the so-called "Huffaker IPM Project" did not have the success expected, mainly because of the difficulty of persuading farmers of the need to first reduce the quantities of pesticides generally used $[6,50]$. As a reaction and to underline the advantages of alternative biological solutions, the expressions "biologically intensive IPM", "biointensive IPM" and "ecologically based IPM" were proposed by various authors [20].

In a general manner, teachers, scientists and technicians themselves did not award the desired importance to this integrated control approach, limiting it at best to its reduced meaning - the management of a single biological pest species in a given crop - whereas in the broad sense it is applied to the harmonious management of all pest populations in their agricultural or forest environment [19]. Its meaning was often the subject of more or less erroneous interpretations, causing a dispersal of the means and efforts devoted to promoting it. Furthermore, the rare supporters of IPM counted on the application of new biotechnologies and unfortunately usually limited themselves to the sometimes extremely elaborate development of pesticide preparations based on biological agents usable in the form of biological treatments comparable with those performed with synthetic pesticides. Various experiences have shown that the gamble was a risky one for agronomic, biotechnical, ecological and economic reasons. Furthermore, the international biopesticides market has stagnated for some twenty years at an insignificant level, forming some $2 \%$ of the world market for pesticides of all kinds. A few rare state laboratories have remained faithful to the original principle of biological control with the introduction-acclimatisation of exotic beneficials, but have discovered the constraints and possible secondary effects of such practices on indigenous fauna and flora. True achievements have nevertheless been made recently in this area, in particular in weed control.

Today, the supporters of so-called integrated farming [9] recommend the implementation to the greatest possible extent of preventive measures and the use of alternative biological solutions (Fig. 2). However, it should be noted that except in special cases these methods are still not sufficiently operational and their inadequate results leave the field open to an organised synthetic pesticides market, at least in the developed countries, whatever the degree of supervision of registration and conditions of application.

\section{THE ECOLOGICAL BASIS OF CROP PROTECTION}

Targeting the population of a biological pest species using the principles of integrated pest management was therefore a significant stage in the recent evolution of phytosanitary protection, even though this new attitude has not yet been adopted by all stakeholders. There is a tendency to move from the control of a pest in a given crop field to the rational management of its populations in the whole farm, or even in several adjoining farms (areawide integrated pest management) [34]. Furthermore, such management of biological pest populations is part of the framework of the overall management of populations closely associated with the same agroecosystem. Drawing up a new crop protection strategy therefore requires the taking into account of the spatio-temporal dimension of the phenomena and involves the development of cropping systems. Overall, farming must now be integrated rationally in the functions of the ecosystems; nature is no longer domesticated [64]. Production objectives in a given socioeconomic framework are therefore logically associated with the environmental constraints of sustainable development of the biosphere.

From the scientific point of view, this new approach was recently enhanced by the increased knowledge of biology, genetics and population ecology. Conservation biology, a new 
Figure 3. Biological diversity, conservation biology, and biological conservation.

Biological diversity or biodiversity has been defined as 'the variety of living organisms considered at all levels of organization, including the genetic, species, and higher taxonomic levels, and the variety of habitats and ecosystems, as well as the processes occurring therein' [44].

'The study of biodiversity and the means to protect it fall within the domain of an emerging science called conservation biology' [33].

'Biological conservation is a more encompassing field than is conservation biology in that it addresses not only the biology, but also the planning, managing, and politics of protecting life's diversity' [33].

synthetic discipline, is therefore attempting to respond to the major challenge raised by the sustainable management of the biosphere through its association of the most recent knowledge in biology with the contributions of the social sciences, economics and political science (Fig. 3). The implementation of the Convention on Biological Diversity is the preferred field of application. Among other general considerations, the Preamble to the Convention mentions (a) the recognised role of biological diversity in the general functioning of the biosphere, (b) the responsibility of humans for reducing it, (c) a general lack of knowledge about taking appropriate measures for conserving it, and (d) the interest of the in situ conservation of ecosystems and natural habitats and of the maintenance and recovery of viable populations of species in their natural surroundings (Rio de Janeiro conference, 1992).

It is estimated that 40 to $50 \%$ of land has been changed or degraded by man with, in particular in agricultural land, a decrease in biological diversity, biological activity and the proportion of organic matter in the soil [40]. The necessary conservation of ecosystems is therefore undertaken through protected zones or sustainable development policies. In Europe, for example, the objective of the Natura 2000 network is the conservation of biodiversity through a network of protected sites where appropriate habitat management is implemented with the taking into account of economic, social and cultural constraints and regional and local features. Accepting such a strategy in agronomy is necessarily the result of a compromise and involves a change in traditional farming systems where productivity is favoured at the expense of quality of the environment and biodiversity.

\subsection{The population-environment system}

Ecologists defines a population as all the individuals of the same species within specified spatial limits. The populationenvironment concept [2] is coherent with this definition by associating the state variables of a population (number, spatial distribution, age structure, genetic structure and social organisation) with the characteristics of a given environment (physicochemical and biological features).

The noteworthy feature of agroecosystems is that humans have mastered, on the one hand, the domesticated animal and plant populations and on the other, farming systems as well as landscape structures. The main difficulty encountered is that within the limits of a given environment all the populations present, or biocoenosis, must be taken into consideration. Ecologists must therefore restrict their fields of action to limited plurispecific sets referred to as populations or communities with a risk of having only a partial view of overall biological diversity.
In an agricultural environment, another feature of these populations is that they are made up of fragmented populations (metapopulations) as a result of the agrarian structures and cropping systems used [31]. In kinetics, wild populations are characterised by local processes of extinction and recolonisation related to the spatial heterogeneity of agroecosystems that disturb their movements and their natural regulation mechanisms. This is why studies of the dispersion of these populations is so successful today, especially at the interfaces of agrarian structures [17]. Recent examination of the spatio-temporal heterogeneity of ecosystems means that movements between the various landscape components must henceforth be considered as a determinant factor in understanding ecological processes [71].

\subsection{The dynamic equilibrium of populations}

It was assumed until recently that ecosystems evolved towards a state of equilibrium defined by the characteristics of soil, climate and vegetation via a series of successive states characterised by an increase in spatial heterogeneity, species diversity and density of populations of organisms, increasing complexity of community organisation and the development of stabilisation mechanisms [65]. Now, the maintaining of agroecosystem equilibrium at some of these intermediate stages is in fact achieved by practices, development operations or cropping or pastoral systems that are called into question today because of their systemic secondary effects such as ploughing, drainage, crop spraying, grazing, etc. [43]. The importance and form of these anthropic contributions determine the different types of agriculture (small farms, extensive, intensive, organic farming, etc.). As a result the application of the general laws of ecology to agroecosystems runs up against their anthropic specificity. This is why the reduction desired in the use of inputs (water, fertilisers and pesticides) implies in return the awarding of an increasing role to better mastery of their management methods and hence deeper knowledge of the functioning of agroecosystems.

The existence of a link between the regulation of these populations and the species diversity of communities is also a subject for discussion between ecologists and pest management specialists. However, it is generally agreed that outbreaks of biological pests are more limited when agroecosystems are more diversified. Entomologists have long attempted to demonstrate the influence of plant diversity on the associated phytophagous fauna. However, they are more frequently interested in the abundance of antagonistic species (predators and parasites) than their true diversity. All the data thus gathered are not enough to affirm, except in rare cases, that crop diversification alone is sufficient to ensure the abundance and diversity desired $[1,39]$. 
Figure 4. Biological control.

Biological control, when considered from the ecological viewpoint as a phase of natural control, can be defined as the action of parasites, predators or pathogens in maintaining another organism's population density at a lower average than would occur in their absence [13].

Biological control means the use of living organisms to prevent or reduce the losses or harm caused by pest organisms [32].

Table I. Some economic assessments of classical biological control programmes (USD million), in Greathead, 1995 [25].

\begin{tabular}{|c|c|c|c|}
\hline Pest & Regions & Savings* & Costs of control programme \\
\hline $\begin{array}{l}\text { Cassava mealybug } \\
\text { Phenacoccus manihoti }\end{array}$ & $\begin{array}{c}\text { Africa } \\
(1984-2003)\end{array}$ & 96.0 & 14.8 \\
\hline $\begin{array}{l}\text { Rhodes grass scale } \\
\text { Antonina graminis }\end{array}$ & $\begin{array}{c}\text { Texas } \\
(1974-1978)\end{array}$ & 194.0 & 0.2 \\
\hline $\begin{array}{l}\text { Skeleton weed } \\
\text { Chondrilla juncaea }\end{array}$ & $\begin{array}{c}\text { Australia } \\
(1975-2000)\end{array}$ & 13.9 & 3.1 \\
\hline $\begin{array}{l}\text { Wood wasp } \\
\text { Sirex noctilio }\end{array}$ & $\begin{array}{c}\text { Australia } \\
(1975-2000)\end{array}$ & 0.8 & 8.2 \\
\hline $\begin{array}{l}\text { White wax scale } \\
\text { Ceroplastes destructor }\end{array}$ & $\begin{array}{c}\text { Australia } \\
(1975-2000)\end{array}$ & 0.09 & 1.4 \\
\hline $\begin{array}{l}\text { Two-spotted mite } \\
\text { Tetranychus urticae }\end{array}$ & $\begin{array}{c}\text { Australia } \\
(1975-2000)\end{array}$ & 0.9 & 0.9 \\
\hline $\begin{array}{l}\text { Potato tuber moth } \\
\text { Phthorimaea operculella }\end{array}$ & $\begin{array}{c}\text { Zambia } \\
(1974-1980)\end{array}$ & 0.09 & 0.04 \\
\hline $\begin{array}{l}\text { Spotted alfalfa aphid } \\
\text { Therioaphis trifolii }\end{array}$ & $\begin{array}{c}\text { USA } \\
(1954-1986)\end{array}$ & 77.0 & 1.00 \\
\hline $\begin{array}{l}\text { Water fern } \\
\text { Salvinia molesta }\end{array}$ & $\begin{array}{c}\text { Sri Lanka } \\
(1987-2112)\end{array}$ & 0.5 & 0.22 \\
\hline
\end{tabular}

* The years in brackets are those of the period used by economists in calculating the discounted profits shown in column 3 as annual 'savings'.

\section{BIOLOGICAL CONTROL: RESULTS AND PROSPECTS}

The idea of natural balance dates back to late nineteenth century naturalists approached by agronomists who wished to reduce harvest losses at a time when demand for produce was increasing rapidly. Traditional agricultural techniques (fallow, cropping sequence and crop rotation) were proving to be inadequate and crop protection procedures were delicate if not dangerous to use and in any case unsuitable for large-scale crops. The successful introduction of two Australasian beneficials, a predatory ladybird (Rodolia cardinalis) and a parasite cryptochetid fly (Cryptochetum iceryae), in Californian citrus orchards devastated by outbreaks of a scale of foreign origin (Icerya purchasi), marked the birth of a new pest control practice, biological control [21].

Unfortunately, its definition is still subject to confusion today. A regrettable ambiguity is still maintained even at the International Organisation for Biological Control of Noxious Animals and Plants (IOBC) as some people limit its field of application to the use of live organisms only to control outbreaks of biological pests $[13,32]$; this contrasts with the interpretations of others who include both these living organisms and inert biological products extracted from them ("botanical pesticides, natural products or bioproducts"). The term biopesticide is thus also a source of the same confusion. The most recent syntheses concerning crop protection $[5,53]$ try to clar- ify the situation by referring to the restrictive definition proposed by DeBach [13] (Fig. 4), also used in this paper. The coherence of his agroecological reasoning centred on the management of living organisms is thus respected.

'Three types of procedure are used in the implementation of biological control: (a) classical biological control: the identification of indigenous and exotic natural enemies, the importation and release of exotic natural enemies, and the evaluation of the abilities of natural enemies to suppress a pest must be performed; (b) augmentation of natural enemies: the culture and release of natural enemies to suppress a pest when a natural enemy is present but in numbers insufficient to provide adequate suppression must be accomplished. Three subsets of this mode are distinguished: inoculation, augmentation, and inundation; (c) conservation of natural enemies: action must be taken to conserve existing natural enemies by preventing their destruction from other practices' [51].

\subsection{Benefits and risks}

After analysis of numerous data according to the criteria of a market economy aiming at immediate profits, the results of classical biological control with the introduction of beneficial organisms are often considered to be inadequate in spite of a few spectacular successes that show that the return on investment can be very high (Tab. I). 
Figure 5. Conservation biological control.

Conservation biological control involves the use of tactics and approaches that incorporate the manipulation of the environment (i.e. the habitat) of natural enemies so as to enhance their survival and/or physiological and behavioural performance, and result in enhanced effectiveness. This approach to biological control can be applied to exotic (i.e. introduced) natural enemies used as part of classical or augmentative biological control programmes as well as to indigenous (native) natural enemies [3].

The future of the biological treatment method by augmentative biological control is considered to be limited for the moment. As mentioned above, the use of biopesticides has not evolved along the lines hoped for by the industry itself over the past 25 years because of the various difficulties involved in the manipulation of living material (patentability, registration, mass reproduction of identical material, specificity of effects, storage and marketing conditions, application).

These methods have nonetheless made it possible to solve frequently critical pest control situations where the problem is the control of species that have accidentally become invasive (weeds, for example) or that of populations that have become resistant to synthetic pesticides (the case of the codling moth Laspeyresia pomonella in apple orchards or the American serpentine leafminer Liriomyza trifolii in greenhouse crops, for example). It must therefore be supposed that the evaluation criteria of the results achieved are not appropriate for the target [28], a question that feeds more general debate on the economic evaluation of biological diversity [40].

Although knowledge is lacking about how to satisfactorily quantify the benefits of biological control, the limits have been better evaluated $[15,68]$. These mainly concern the environmental consequences of the acclimatisation of exotic living organisms used as biological control agents, whether such consequences are direct effects on non-target indigenous species or indirect effects on the communities concerned; the hypothesis has even been put forward that the extinction of species may be a result of biological control operations, in particular in island environments. Fortunately, these various disadvantages can be reduced or even avoided by in-depth studies of the activity spectrum of potential beneficials before they are introduced: such as, for example, the centrifugal phylogenetic testing recommended in biological control of weeds $[4,12]$. The introduction of beneficial organisms is also the subject of strict recommendations by FAO, which drew up an international Code of Conduct for the Import and Release of Exotic Biological Control Agents in 1995 for national quarantine services [56].

\subsection{Environmental management, a preliminary and necessary step?}

The recent progress of knowledge in conservation biology fortunately gives us an opportunity to revise our traditional view of biological control by awarding priority to the conservation of populations of beneficial organisms and hence the conservation of their habitats [22, 38, 52], (Fig. 5). A fair proportion of the failures recorded in the classical introduction-acclimatisation method can probably be ascribed to a varying degree of unsuitability of the environmental conditions of the receiving agroecosystem (Tab. II). This is the defect that so-called conservation biological control intends to correct. Furthermore,
Table II. Summary of classical biological control results using insect agents to control insect pests and weeds, in Greathead, 1995 [25].

\begin{tabular}{lcc}
\hline & Insect pests $(\mathrm{N})$ & Weeds $(\mathrm{N})$ \\
\hline Introduction & 4769 & 692 \\
Establishment & 1445 & 443 \\
Target pests & 543 & 115 \\
Good control & 421 & 73 \\
Countries or islands & 196 & 55 \\
\hline
\end{tabular}

the attention recently paid to the dynamic balance of populations was a reminder of the hitherto neglected role played by indigenous predatory faunae $[11,58]$ and stimulated its re-evaluation in the regulation of biological pest populations. However, it should be remembered that concern for developing habitats prior to the implementation of biological control procedures had not escaped the perspicacity of precursors, even if their recommendations were not followed by effects in their time [63].

The role played by biological corridors between habitats and the edge effect on the distribution of biological pests and their parasite complexes is beginning to receive attention in crop protection $[27,29,36,42,59,67]$. It is true that biological corridors can only really be exploited in a collective strategy - generally contractual - of conservation of biological diversity as a whole. Although the research sector has only paid limited attention to the subject so far, the preliminary conclusions generally support the idea that large, interconnected habitats are favourable for biological diversity and population stability [35, 61].

In contrast, the edge effect can easily be used by the farmer himself on his own initiative and on the scale of his own farm. Thus, in Switzerland ecological compensation areas (ECA) are recommended in various forms (tracks, hedges and copses and also orchards, extensive pasture, etc.) and are subsidised if they form at least $7 \%$ of total farm area. The procedures used most frequently are wildflower strips 3-m wide, rotating fallows and field edges left unsprayed to widths of 3 to $12 \mathrm{~m}$, referred to as conservation headlands. The technique is taken to the point at which a mixture of about 30 indigenous herbaceous species (annual, biannual and perennial) are specially chosen for these strips and intended to be left for a period of 2 to 6 years [57]. Experimental farms are designed for testing these new techniques $[10,62,66]$. With the same aim of enhancing beneficial fauna, the food properties (pollen, nectar) of these strips planted for parasitoid beneficials, and also referred to as grassy banks or beetle banks, receive particularly close study [37, 70]. For large-scale cultivation as used for cotton both in Australia and the United States, they can be usefully replaced by strips of rapeseed, wheat or alfalfa set within the main crop $[45,48]$. The procedure is called strip-cropping or strip-intercropping and is part of the new cropping systems mentioned below [41, 60]. The new techniques are also used in sheltered cropping insofar 
Figure 6. Objectives of habitat management with a view to the increased efficacy of biological control agents.

'Habitat management regimes to increase natural-enemy effectiveness are directed at:
- enhancing habitat suitability for immigration and host finding
- provision of alternative prey/hosts at times when the pest is scarce
- provision of supplementary food sprays, pollen and nectar for predators and parasitoids
- provision of refugia (for mating or overwintering)
- maintenance of non-economic levels of the pests or alternative hosts over extended periods to ensure continued survival of natural enemies' [39].

Figure 7. The general principles of integrated farming.

Multifunctional crop rotation, integrated nutrient management, minimum soil cultivation, integrated crop management, ecological infrastructure management and implementing an integrated system [30].

as the development of the spaces between the greenhouses or shelters also contributes to the management of populations of biological pests and beneficials [49]. In a more general manner, Letourneau and Altieri [39] listed the objectives of the conservation or development of the habitats of beneficials (Fig. 6). Care is obviously taken in the choice of plant species for these habitats to avoid those that might form reservoirs of undesirable pathogenic organisms.

\section{CROP PROTECTION AND INTEGRATED FARMING}

In the light of the new importance thus awarded to the interactions between crop fields and their immediate biological environment, agronomists are faced with the same obligation to develop their strategies as pest management specialists [14, 47]. It is now necessary to broaden the cropping system concept and to use a less physicochemical view of the environment than in the past. It is also noted that the concepts in English of "cropping system" and "farming system" apply to larger areas and sometimes that of a small region, thus intersecting the idea of areawide pest management mentioned above. These refinements benefit today from the use of models of the functioning of agroecosystems that use artificial intelligence or multicriterion decision aid methods [7, 46, 47].

Numerous bibliographical data make it possible to address the characterisation of agrosystems that discourage biological pest outbreaks: great spatio-temporal diversity of crops, discontinuity in monoculture (rotations, early varieties, etc.), a mosaic of small fields to ensure the juxtaposition of cultivated and non-cultivated land, the presence of a dominant perennial crop (especially orchards), crops grown with high sowing density to limit weed populations, great genetic diversity in the crops grown (varieties grown mixed or alternate rows of crops). Various recommendations concerning the management of cultivated plants and the choice of cropping techniques are then made, for example, for the drawing up of crop management strategies: the spatio-temporal dimension, the composition and abundance of the indigenous flora in and around the fields, soil type, the nature of the environment and the type of farm [39].

Stress is also laid on preventive techniques to protect crops against biological pests, whereas the most commonly used technique today is the curative method using chemical pesticides. The biological control and environmental practices proposed above form part of a larger set of preventive techniques such as those generated by genetics [16], but that have the originality of addressing the sustainable exploitation of agroecosystems. In a forward-looking analysis of the evolution of crop protection, Ferron and Deguine [23] drew up the basis for a new phytosanitary strategy calling on the two methods in a structured, ranked manner without ruling out the use of curative control methods under well-defined conditions as a last resort. Given the variability of biological phenomena and the need to conserve the profits of a harvest, the implementation of the strategy requires respect of a planned spatio-temporal conception of the management of the farm.

\section{CONCLUSION}

The adoption of such a preventive approach to crop protection forms a break with the practices recommended up to now. It therefore requires an effort in education, design and development, adaptation to local conditions, validation and extension that concerns all the sector stakeholders. The proposal follows the trend of the approach undertaken by FAO with a view to drafting good farming practices on the basis of the Common Codex for Integrated Farming as in that of a "Doubly Green Revolution" [26, 55]. The position awarded to agronomic techniques implies that agronomists once again play a driving role in the evolution of this discipline, in particular by making cropping systems and techniques evolve according to the principles of integrated farming [8, 30] (Fig. 7). The wish for better synergy between ecology and agronomy for the benefit of sustainable exploitation of the biosphere could thus be granted [69].

\section{REFERENCES}

[1] Andow D., Vegetational diversity and arthropod population response, Annu. Rev. Entomol. 36 (1991) 561-585.

[2] Barbault R., Écologie générale. Structure et fonctionnement de la biosphère, Masson, Collection Enseignement des Sciences de la Vie, Paris, 4${ }^{\mathrm{e}}$ ed., 1997. 
[3] Barbosa P. (Ed.), Conservation Biological Control, Academic Press, San Diego, London, 1998.

[4] Barrat B.I.P., Risks of biological control, in: Pimentel D. (Ed.), Encyclopedia of Pest Management, Marcel Dekker, Inc., New York, Basel, 2002, pp. 720-722.

[5] Bellows T.S., Fisher T.W. (Eds.), Handbook of Biological Control. Principles and Applications of Biological Control, Academic Press, San Diego, London, 1999

[6] Benbrook C.M., Pest Management at the Crossroads, Consumer's Union, Yonkers, NY, 1996.

[7] Boiffin J., Malézieux E., Picard D., Cropping Systems for the Future, in: Nösberger J., Geiger H.H., Struik P.C. (Eds.), Crop Science: Progress and Prospects, Cabi, Wallingford, UK, 2001, pp. 261-279.

[8] Boller E.F., Malavolta C., Jörg E., Guidelines for Integrated Production of Arable Crops in Europe. Technical Guidelines III, IOBC wprs Bull./OILB wprs Bull. 20 (1997) 21-39.

[9] Bonny S., L'agriculture raisonnée, l'agriculture intégrée et Farre Forum de l'agriculture raisonnée respectueuse de l'environnement, Nat. Sci. Soc. 5 (1997) 64-71.

[10] Booij K., Dynamics of Thrips tabaci in diversified agro-ecosystems, a modeling approach, IOBC wprs Bull./Bull. OILB srop 26 (2003) 19-24.

[11] Bommarco R., Ekbom B., Landscape management and resident generalist predators in annual crop systems, in: Ekbom B., Irwin M.E., Robert Y. (Eds.), Interchanges of Insects between Agricultural and Surrounding Landscapes, Kluwer Academic Publishers, Dordrecht, 2000, pp. 169-182.

[12] Briese D.T., Phylogeny: can it help us to understand host choice by biological weed control agents? in: Moran V.C., Hoffmann J.H. (Eds.), Proceedings of the IX International Symposium on Biological Control of Weeds, 19-26 January 1996, Stellenbosch, University of Cape Town, South Africa, 1996, pp. 19-26.

[13] DeBach P. (Ed.), The scope of biological control, Biological control of insect pests and weeds, Chapman \& Hall, London, 1964, pp. $3-$ 20.

[14] Deffontaines J.P., Introduction. Une agronomie en questionnement, C.R. Acad. Agric. France 87 (2001) 115-119.

[15] Duan J.J., Follett P.A. (Eds.), Nontarget Effects of Biological Control, Kluwer Academic Publishers, Norwell, MA, 2000.

[16] Durand-Tardif M., Candresse T., Apport de la génétique à la protection des plantes, Biofutur 242 (2004) 16-23.

[17] Ekbom B., Irwin M., Robert Y. (Eds.), Interchanges of Insects between Agricultural and Surrounding Landscapes, Kluwer Academic Publishers, Dordrecht, NL, 2000.

[18] El Titi A., Boller E.F., Gendrier J.P., Integrated Production - Principles and Technical Guidelines, IOBC wprs Bull./Bull. OILB srop 16 (1993).

[19] FAO, Report of the first session of the FAO Panel of Experts on Integrated Pest Control, Rome, Italy, Sept. 18-22, 1967.

[20] Ferron P., Protection intégrée des cultures : évolution du concept et de son application, Cah. Agr. 8 (1999) 386-396 (and Dossiers de l'environnement de l'INRA 19 (1999) 19-28).

[21] Ferron P., La lutte biologique : définition, concept et stratégie, in: Fraval A., Silvy C., La lutte biologique II, Dossier de l'environnement de l'INRA 19 (1999) 7-17 (and in: ACTA (Ed.), Pesticides et protection phytosanitaire dans une agriculture en mouvement, Paris, 2002, pp. 279-298)

[22] Ferron P., Bases écologiques de la protection des cultures, Gestion des populations et aménagement de leurs habitats, Courrier de l'environnement de l'INRA 41 (2000) 33-41.
[23] Ferron P., Deguine J.-P., Vers une conception agro-écologique de la protection des cultures, in: Regnault-Roger C. (Ed.), Enjeux phytosanitaires pour l'agriculture et l'environnement au XXI ${ }^{\mathrm{e}}$ siècle, Tec et Doc Lavoisier, Paris, in press.

[24] Glass E.H. (Ed.), Integrated pest management: rationale, potential, needs and implementation, Entomol. Soc. Am., Special Publ. 752 (1975).

[25] Greathead D.L., Benefits and risks of classical biological control, in: Hokhanen H.M.T., Lynch J.M. (Eds.), Biological control, Benefits and risks, Cambridge University Press, Plant and Microbial Biotechnology Research, Series 4, 1995, pp. 53-63.

[26] Griffon M. (Ed.), Vers une Révolution Doublement Verte, Actes du séminaire des 8-9 novembre 1995, Futuroscope, Poitiers, Cirad, Nogent-sur-Marne, 1996.

[27] Gurr G.M., Wratten S.D., Irvin N.A., Hossain Z., Baggen L.R., Mensah R.K., Walker P.W., Habitat manipulation in Australasia: recent biological control progress and prospects for adoption, in: Zalucki M.P., Drew R.A.I., White G.G. (Eds.), Pest Management. Future Challenges, Proceedings of the Sixth Australasian Applied Entomological Research Conference, The University of Queensland, Brisbane, Australia, Vol. 2, 1998, pp. 225-235.

[28] Gutierrez A.P., Caltagirone L.E., Meikle W., Evaluation of Results. Economics of Biological Control, in: Pimentel D. (Ed.), Encyclopedia of Pest Management, Marcel Dekker, Inc., New York, Basel, 1999, pp. 243-252.

[29] Häni F.J., Boller E.F., Keller S., Natural Regulation at the Farm Level, in: Pickett C.H., Bugg R.L. (Eds.), Enhancing Biological Control. Habitat Management to Promote Natural Enemies of Agricultural Pests, Univ. California Press, USA, 1998, pp. 161210.

[30] Holland J.M., Integrated Farming Systems, in: Pimentel D. (Ed.), Encyclopedia of Pest Management, Marcel Dekker, New York, 2002, pp. 410-412.

[31] Hunter M.D., Landscape structure, habitat fragmentation, and the ecology of insects, Agr. Forest Entomol. 4 (2002) 159-166.

[32] IOBC / OILB, Statutes. IOBC wprs Bull./OILB srop Bull. 1973/1 (1973).

[33] Knight R.L., Landres P.B., Central Concepts and Issues of Biological Conservation, in: Gutzwiller K.J. (Ed.), Applying Landscape Ecology in Biological Conservation, Springer-Verlag, New York, Berlin, Heidelberg, 2002, pp. 22-33.

[34] Kogan M., Aerawide pest management, in: Pimentel D. (Ed.), Encyclopedia of Pest Management, Marcel Dekker, Inc., New York, Basel, 2002, pp. 28-32.

[35] Kruess A., Tscharntke T., Effects of habitat fragmentation on plant-insect communities, in: Ekbom B., Irwin M.E., Robert Y. (Eds.), Interchanges of Insects between Agricultural and Surrounding Landscapes, Kluwer Academic Publishers, Dordrecht, 2000, pp. 53-70.

[36] Landis D.A., Marino P.C., Landscape Structure and Extra-Field Processes: Impact on Management of Pests and Beneficials, in: Ruberson J.R. (Ed.), Handbook of Pest Management, Marcel Dekker, New York, 1999, pp. 79-104.

[37] Landis D.A., Wratten S.D., Gurr G.M., Habitat management to conserve natural enemies of arthropod pests in agriculture, Annu. Rev. Entomol. 45 (2000) 175-201.

[38] Letourneau D.K., Conservation Biology: Lessons for Conserving Natural Enemies, in: Barbosa P. (Ed.), Conservation Biological Control, Academic Press, San Diego, London, 1998, pp. 9-38.

[39] Letourneau D.K. Altieri M.A., Environmental Management to Enhance Biological Control in Agroecosystems, in: Bellows T.S., Fisher T.W. (Eds.), Handbook of Biological Control. Principles and Applications of Biological Control, Academic Press, San Diego, London, 1999, pp. 319-354. 
[40] Lévêque C., Mounolou J.-C., Biodiversité. Dynamique biologique et conservation, Editions Dunod, Collection Masson Sciences, Paris, 2001.

[41] Lys J.A., The positive influence of strip-management on ground beetles in a cereal field: increase, migration and overwintering, in: Desender K., Dufrene M., Loreau M., Luff M.L., Maelfait J.P. (Eds.), Carabid Beetles: Ecology and Evolution, Kluwer, Dordrecht, 1994, pp. 451-455.

[42] Marino P.C., Landis D.A., Effect of landscape structure on parasitoid diversity and parasitism in agroecosystems, Ecol. Appl. 61 (1996) 276-284.

[43] McLaughlin A., Mineau P., The impact of agricultural practices on biodiversity, Agr. Ecosyst. Environ. 55 (1995) 201-212.

[44] Meffe G.K., Carroll C.R. (Eds.), Principles of Conservation Biology, Sinauer Associates, second edition, Sunderland, Massachussetts, 1997.

[45] Mensah R.K., Habitat diversity: implications for the conservation and use of predatory insects of Helicoverpa spp. in cotton in Australia, Int. J. Pest Manage. 45 (1999) 91-100.

[46] Meynard J.M., La modélisation du fonctionnement de l'agrosystème, base de la mise au point d'itinéraires techniques et de systèmes de culture, in: Biarnes A. (Ed.), La conduite du champ cultivé : point de vue d'agronomes, ORSTOM, Paris, 1998, pp. 30-54.

[47] Meynard J.M., Dore T., Habib R., L'évaluation et la conception de systèmes de culture pour une agriculture durable, C.R. Acad Agric. France 87 (2001) 223-226.

[48] Parajulee M.N., Slosser J.E., Evaluation of potential relay strip crops for predator enhancement in Texas cotton, Int. J. Pest Manage. 45 (1999) 275-286.

[49] Parella M.P., Stengarf Hansen L., van Lenteren J., Glasshouse Environments, in: Bellows T.S., Fisher T.W. (Eds.), Handbook of Biological Control. Principles and Applications of Biological Control, Academic Press, San Diego, London, 1999, pp. 819-839.

[50] Perkins J.H., Insects, Experts, and the Insecticide Crisis. The quest for new pest management strategies, Plenum Press, New York, 1982.

[51] Perkins J.H., Garcia R., Social and Economic Factors Affecting Research and Implementation of Biological Control, in: Bellows T.S., Fisher T.W. (Eds.), Handbook of Biological Control. Principles and Applications of Biological Control, Academic Press, San Diego, London, 1999, pp. 993-1009.

[52] Pickett C.H., Bugg R.L. (Eds.), Enhancing Biological Control: Habitat Management to Promote Natural Enemies of Agricultural Pests, University of California Press, Berkeley, USA, 1998.

[53] Pimentel D. (Ed.), Encyclopedia of Pest Management, Marce Dekker, Inc., New York, Basel, 2002.

[54] Rabb R.L., Guthrie F.E., Concepts of pest management, Proceedings, North Carolina State University, Raleigh, N.C., 1970.
[55] Ribier V., Griffon M., Quelles politiques agricoles pour accompagner la révolution doublement verte ? C.R. Acad. Agric. France (2004) in press.

[56] Schulten G.G.M., The FAO Code of Conduct for the Import and Release of Exotic Biological Control Agents, in: Smith I.M. (Ed.), EPPO/CABI Workshop on Safety and Efficacy of Biological Control in Europe, Blackwell Science Ltd, Oxford, 1997, pp. 29-36.

[57] Studer S., Eggenschwiler L., Jacot K., Ecological compensation areas - the Swiss approach to enhance faunistic and floristic diversity in agricultural landscapes, IOBC wprs Bull./Bull. OILB srop 26 (2003) 151-156.

[58] Symondson W.O.C., Sunderland K.D., Greenstone M.H., Can Generalist Predators be Effective Biocontrol Agents? Annu. Rev. Entomol. 47 (2002) 561-594

[59] Thomas M.B., Wratten S.D., Sotherton N.W., Creation of "island" habitats in farmland to manipulate populations of beneficial arthropods: predator densities and emigration, J. Appl. Ecol. 28 (1991) 906-917.

[60] Trenbath B.R., Intercropping for the management of pests and diseases, Field Crop. Res. 34 (1993) 381-405.

[61] Tshernyshev W.B., Why do outbreaks of pests in agroecosystem arise? IOBC wprs Bull./Bull. OILB srop 26 (2003) 179-184.

[62] van Alebeek F.A.N., Kamstra J.H., Venhorst B., Visser A.J., Manipulating biodiversity in arable farming system for better pest suppression: which species at what scale? IOBC wprs Bull./Bull. OILB srop 26 (2003) 185-190.

[63] van den Bosch R., Telford A.D., Environmental modification and biological control, in: DeBach P. (Ed.), Biological control of insects pests and weeds, Chapman \& Hall, London, 1964, pp. 459-488.

[64] Vandermeer J., The ecological basis of alternative agriculture, Annu. Rev. Ecol. Syst. 26 (1995) 201-224.

[65] Vandermeer J., van Noordwijk M., Anderson J., Ong C., Perfecto I., Global change and multispecies agroecosystems: Concepts and issues, Agr. Ecosyst. Environ. 67 (1998) 1-22.

[66] Vereijken P., A methodical way of protyping integrated and ecological arable farming systems (I/EAFS) in interaction with pilot farms, Eur. J. Agron. 7 (1997) 235-250.

[67] Verkerk R.H.J., Leather S.R., Wright D.J., The potential for manipulating crop-pest-natural enemy interactions for improved insect pest management, B. Entomol. Res. 88 (1998) 493-501.

[68] Wajnberg E., Scott J.K., Quimby P.C. (Eds.), Evaluating Indirect Ecological Effects of Biological Control, CABI Publishing, CAB International, Wallingford, Oxon, UK, 2000.

[69] Weber J., Enjeux de biodiversité pour l'agriculture, C.R. Acad. Agric. France (2004) in press.

[70] Wratten S., Lavandero B., Scarratt S., Vattala D., Conservation biological control of insect pests at the landscape scale, IOBC wprs Bull./Bull. OILB srop 26 (2003) 215-220.

[71] Yoccoz N.G., Nichols J.D., Boulinier T., Monitoring of biological diversity in space and time, TREE 16 (2001) 446-453. 